UDC 33

DOI: $10.15587 / 2313-8416.2015 .36928$

\title{
THE FUTURE OF INSURANCE AGENT AS A PARTNER IN A COMPANY'S OPERATING ACTIVITY
}

\author{
(C) Janowski Andrzej
}

Every business operates in conditions of uncertainty caused by various fortuitous events. Such events derive from objectively existing dangers, i.e. risks, which cannot be avoided by companies. The risks are not only connected to business activity, but they also pose a threat to human life and health. There exists a possibility to secure oneself against financially negative outcomes of those risks by becoming insured against fortuitous events Keywords: agent, effectiveness, human performance, human resources management, insurance company, opportunities

Кожен бізнес працює в умовах невизначеності, викликаної різними випадковими подіями. Такі подіі відбуваються через об'єктивно існуючі небезпеки, тобто ризики, які не можуть бути усунені за допомогою компаній. Ризики пов'язані не тільки з підприємницькою діяльністю, вони також становлять загрозу для життя і здоров'я людини. Існує можливість убезпечити себе від фінансово негативних наслідків цүих ризиків, стаючи застрахованим від випадкових подій

Ключові слова: агент, ефективність, працездатність людини, управління людськими ресурсами, страхова компанія, можливості

\section{Introduction}

In the current socio-economic relations, especially those based on market mechanisms, such insurance, can take two forms: one can gather funds on one's own in order to cover financial losses incurred by the risks (fortuitous events), or can transfer this financial burden to a specialized and qualified entrepreneur [1]. Practice has proven, that the second option is a more economic and rational solution, which is provided by an institution established especially for that purpose. By definition, insurance it is a service which task (goal) is to mitigate (or fully eliminate) negative results of fortuitous events by placing the burden of such mitigation on many individual units threatened with such events (One can assume that the nature and character of business insurance are best reflected by the legal definition of insurance stated, for example, in Article 805 of the Polish Civil Code: "By the contract of insurance the insurer undertakes within the scope of his enterprise's activity to render specified performance when an accident envisaged in the contract occurs and the insuring party undertakes to pay a premium”). Referring to this service, an entity can get rid itself from the financial problem connected to random losses, which it cannot influence and which are potentially inevitable. The service is a rather inexpensive and effective measure to solve problems originating from a difficult financial situation. In this context, insurance can provide funds, and thus, restore the entity's economic (financial) position, which it had before the damage had been incurred (microeconomic approach), and also ensure steady and stable functioning of the whole national economy (macroeconomic approach).

All economic processes, and thus, the institutions that provide services within them, have not only economic, but also social character since they are the source of various human relations and, therefore, influence the living conditions of members of a society.
In all countries where economic relations are based on market economy rules, insurance companies are an important element of the supply system of social security scheme. Market economy generates and inspires the development of life insurance system, and hence, from the social point of view, it attributes basic significance to such insurance. A significant part of a society in the preand post-working age cannot count on the desired material security to be provided to them by the state when they retire. Hence, they complement the state care by purchasing individual insurance policies, mostly for life and disability. Therefore, life insurance becomes a crucial social tool, that enables to solve many problems of aging societies, which, according to population forecasts, Poles can be a part of soon. As regards individuals, the financial help of personal accident insurance or life insurance in case of a death in the family (group life insurance) or death of the breadwinner cannot be overestimated. The social significance of business insurance policies, mainly the personal ones, is dependent on the so-called insurance awareness. At the moment, in Poland personal insurance does not fulfil its potential role to sufficient extent.

\section{Literature review}

\subsection{Sources of insurance law}

The sources of insurance law are the forms in which the state's intentions concerning insurance issues is expressed and demonstrated to an entrepreneur (a natural or legal person). Sources of different branches of law, including one of the comprehensive branches, i.e. business insurance law, are examined and shown in such a formal context.

Business insurance law, in contrast to most of the basic branches of law, is not codified. Thus, its sources are dispersed and can be found in numerous normative acts (mainly government acts, regulations and decrees). Among them, The Insurance Activity Act [2] and 1964 
Civil Code are of special significance. Moreover, Act of 22 May 2003 on Insurance Mediation [3] founded rules for property and personal insurance mediation.

\section{2. Insurance mediation}

Insurance mediation consists in the performance, for remuneration, of factual or legal acts involved in the conclusion and performance of insurance contracts. Insurance mediation is performed exclusively by insurance agents or insurance brokers, and it is a business activity, as defined in the provisions of Act of 19 November 1999 [4]. Insurance agent undertakes:

- acts in the name and on behalf of the insurance undertaking, referred to as "agency acts" consisting in: soliciting of clients, carrying out work preparatory to the conclusion of insurance contracts, conclusion of insurance contracts and assisting in the administration and performance of insurance contracts, also in the event of a claim, as well as in the organisation of and supervision over agency acts (agency activities).

An insurance broker:

- acts in the name and on behalf of an entity seeking insurance coverage, referred to as „brokerage acts", consisting in: the conclusion of or leading to the conclusion of insurance contracts, performing work preparatory to the conclusion of insurance contracts and participation in the management and execution of insurance contracts, also in the event of a claim.

\section{3. Insurance agent}

An insurance agent is an entrepreneur performing agency activities under an agency contract concluded with an insurance company and entered in the register of insurance agents. Agency acts may be performed exclusively by a natural person who meets all the following requirements:

a) is possessed in full of the legal capacity;

b) has not been finally sentenced for a wilful commission of an offence:

- against life and death;

- against administration of justice;

- against protection of information;

- against credibility of documentation;

- against property;

- against economic trading;

- against trading in money and securities;

- treasury; activities;

c) guarantees the due performance of agency

d) has at least secondary education;

e) has undergone training run by an insurance undertaking that ended with a passed examination.

\section{Situation on the life insurance market in Poland after 1990}

The modern insurance market in Poland started developing on 28th July 1990, which is the day when the Insurance Activity Act was passed. The Act eliminated insurance monopoly of the state and allowed for establishing private insurance agencies with national or foreign capital. This marked the beginning of a sort of revolution in insurance and made it possible to institutionalise the insurance market owing to a 1995 amendment. The monopoly of Państwowy Zakład Ubezpieczeń (the National Insurance Agency) was replaced by the free competition one, where all insurers could conduct their insurance business, and relating to a growing competition, customers were able to choose higher-quality products [5]. At that time, the market was undergoing the free market economy processes and the greatest emphasis was put on making the society interested in the new services. In 1993, PZU Życie was the leader in the area of life insurance. It gathered $99.2 \%$ of premiums in this group, followed by Commercial Union na Życie and Amplico Life. Although PZU Życie had at the time and will have the largest share in the market, it has been gradually losing a few percentage points every year to its competitors. In 1993, the premiums collected from life insurance policies amounted to $28.5 \%$ of all the income from insurance premiums [6].

In the years 1993-1994, decreasing the number of life insurance contracts was observed. This process was influenced by a negative opinion on a few insurance policies taken out by PZU clients, which had depreciated due to hyperinflation (500-700\% per year) at the end of the 1980s and the beginning of the 1990s. The fear of novelty was the dominating feeling at the time.

In 1995 (owing to an Insurance Activity Act amendment) organizational and institutional structure of the insurance market was created. The insurance market started functioning in accordance with free market economy rules.

Since the Insurance Activity Act amendment was introduced, the insurance market in Poland entered the right development path. A framework for proper functioning of the market was created. Nonetheless, formal adjustment and "maturation" of the market was a process, which took many years. According to the European insurance and reinsurance federation CEA, in 1995 and 1996, the Polish insurance market belonged to one of the most dynamically developing markets in Europe.

Since the beginning of the 1990s, Poland was a very attractive insurance market. There were cases of "testing" when the social insurance reform was being introduced: firstly, universal pension fund companies were established, and only then were strictly insuring businesses set up (e.g. Norwich Union Życie S. A.), or some companies returned to the market after being absent for a few dozen years (Generali Życie TU). With new participants entering the market, competitiveness increased, which benefited clients and contributed to the development of life insurance in terms of quality. The existing limitations concerning access of foreign insurers to the Polish market became less strict.

Additionally, what influenced the Polish life insurance market were also social insurance and healthcare sector reforms, which began in 1999. They raised awareness of insurance and legislative needs and, at the same time, opened up new opportunities to manage capital in order for it to protect and secure the future. In 1990, there were only two insurance companies in category 1 (life insurance), whereas in 2002 the life 
insurance market was shared between 35 insurance agencies (nine companies with Polish capital and 26 with foreign one).

\section{Insurance agent efficiency as an important} factor for the creation of sales strategies of life insurance companies

Insurance agents serve as a link between the demand and the supply of the insurance market, so they have always been its crucial participants, especially in the context of of life insurance. It is not surprising then, that the number of agents is growing proportionally to the level of concluded life insurance contracts (demand growth). Yet, it seems to be authorized to claim, that insurance agents play a different role in the life insurance business than in the property one. Most of all, life insurance is not an obligation, so the agent's role does not only consist in simple, mechanical dealing of a contract, as is often the case with obligatory insurance. (Additionally, life insurance is a long-term contract, so the decision whether to sign it should be well-thoughtout. It is understandable how important the role of an agent may be here. An agent is more of a financial advisor than an insurance company representative (as, for example, Financial Planning Advisers operating in the $U K)$.

The first life insurance policies were sold with the help of the same network structures and property insurance agencies that had already existed on the market. What they did was simply add another product to their existing foreign structures, simultaneously building a foundation for their own organizational systems and searching for their own distribution channels. Since centrally-planned economy did not require any marketing activities, as there was a product shortage in the market, the easiest form of recruitment (today, completely ineffective) was to publish a job offer in a newspaper, which at the time, proved to be very effective (Table 1).

The advent of management processes aimed at adjusting the Polish economy to the free market rules, opening the Polish borders to the West and some characteristic traits of Poles as a nation which made them very economically active, caused numerous teachers, ex- soldiers and police officers to take part in a two- or threeday training conducted by insurance companies and be honoured with the name of an insurance agent (since at the time there existed a rather negative prejudice connected to the word "agent", insurance intermediaries used to write on their first business cards the word "adviser").

Table 1

Effectiveness of recruiting the most successful agents

\begin{tabular}{|c|c|}
\hline Recruitment method & Effectiveness [\%] \\
\hline Job offer in the press & 21 \\
Manager's activity Agent's & 20 \\
activity & 26 \\
Information from friends & 20 \\
Other & 13 \\
\hline
\end{tabular}

Source: the author's own research [Survey $(n=500)$ conducted in April 2012 during a Commercial Union congress for the best agents]

The knowledge acquired during a few-day training was definitely insufficient to present an offer of even the simplest insurance product in a competent way, but the paradox was, that the optimism instilled in the future market practitioners substituted many of their theoretical and practical shortcomings. Coupled with an "unshakeable faith" of a salesperson, coming from few advertising leaflets, it was enough to convince a potential purchaser (usually a friend or a neighbour) to make this rather important decision concerning a long-term relationship with a financial institution, which was particularly impressive taking into consideration that the general terms usually contained a provision that the purchaser could not withdraw the money for at least 3 years while the amount of the capital that would be gathered in those 36 months of systematic saving was not specified directly in the contract. In order for an insurance company to obtain a return on the invested capital, the recruitment process was constructed in such a way as to verify positively every person who had a full capacity to perform acts in law and had not been in conflict with the law, so the number of agents increases systematically (Table 2).

The number of registered agents 2005-2011

\begin{tabular}{|c|c|c|c|c|c|c|c|}
\hline The registered insurance agents & 2005 & 2006 & 2007 & 2008 & 2009 & 2010 & 2011 \\
\hline Exclusive agents & 22900 & 23000 & 24600 & 23300 & 23400 & 22700 & 20900 \\
\hline Multi agents & 12700 & 13800 & 14700 & 15300 & 16400 & 15100 & 14500 \\
\hline Agents Total & 35600 & 36800 & 39300 & 38600 & 39800 & 37800 & 38600 \\
\hline
\end{tabular}

Source: Committees of Financial Supervision [www.knf.gov.pl]

In order for contracts to be concluded with as few mistakes as possible (one computational mistake could be made during the calculation of the premium), some life insurance companies took a minimum of a yearly premium when a client was signing the contract, and the insurance cover was very limited: the money was paid out only when the insured person died.
4. Insurance agent: partner in business or a pawn to achieve the shareholders' goals?

Insurance companies use the following distribution channels (Table 3):

- direct sales (by fulltime company employees)

- agency sales by insurance agents

- sales by insurance brokers 
Table 3

The service distribution channels of insurance companies, in 2007-2013 [in \%]

\begin{tabular}{|c|c|c|c|c|c|c|c|}
\hline Specification & 2007 & 2008 & 2009 & 2010 & 2011 & 2012 & 2013 \\
\hline Direct sale & 27,3 & 22,9 & 32,4 & 36,8 & 34,6 & 28,8 & 40,2 \\
\hline Agent sale & 66,3 & 72,5 & 62,5 & 52,6 & 55,9 & 63,0 & 56,8 \\
\hline Brokers sale & 2,4 & 1,6 & 1,8 & 1,7 & 1,9 & 1,6 & 1,8 \\
\hline Other & 3,9 & 3,0 & 3,3 & 8,9 & 7,7 & 6,6 & 1,1 \\
\hline
\end{tabular}

Source: Committees of Financial Supervision [www.knv.gov.pl]

Direct sales by insurance company employees is characterised by large quantities, which actually do not reflect the sales effectiveness as mediation activities are carried out not only by those employees, but also people working in banks, travel agencies and also postmen. However, this distribution channel remains the cheapest source of insurance sales (an agent or a broker should be paid a commission reaching $90 \%$ of the first-year premium). As can be concluded from the table mentioned above, the share of insurance agents in all the insurance company product distribution is very high and it remains on the same level. Nevertheless, some problems can be noticed that derive from previous activities in the area of sales strategy. They could have been caused by the following factors:

- most people started working on the primary market, which had considerably changed. The old sales techniques, very effective thus far, do not reap the desired results: a 2014 client is more aware and more demanding,

- the second problem is maintaining the clients and providing services to them. There used to be a growing tendency in the insurance market. However, after the Polish pension reform, there came a breakthrough and the insurance company client market became more mature, which has had some consequences. At the same time, the economic recession started so the group of potential clients shrank,

- advertising campaign in the media has shaped a specific type of social awareness. Many Poles are already insured for life and convinced that the financial instrument, which they chose, will solve $100 \%$ of their financial problems when they retire. However, they do not understand the real nature of its mechanisms. Actually, the effectiveness of a life insurance policy as a source of gathering capital is doubtful to say the least.

At the moment, an observed decreasing number of insurance policies demonstrates an undeniable fact, that those, who used to sell the most, were not necessarily the best sellers. There even appeared a term "misselling", meaning wrong sales. Superinvestment provided with extra protection has turned out to be something different than it was supposed to be.

This is a phenomenon that can be encountered in every country since no strategy, not even the most perfect one, is able to prevent people who have some undesirable traits in the profession of an insurance agent from becoming such agents. A grotesque copy of management through objectives with many elements of X McGregor's theory [7] was used on a large scale by organizations, which offered life insurance and this approach now takes its toll. An agent should not only have an inherent educational talent, but also a detailed and reliable knowledge. They should be able to demonstrate to the client how the value of money changes in time. A highly-qualified advisor should be able to calculate the percentage value of single premiums or those paid in instalments (monthly, quarterly, yearly premiums). They should be able to estimate profits and to calculate. Unfortunately, sometimes clients welcome to their houses employees who do not possess proper qualifications. One can even opine that those who manage insurance companies deliberately concealed some information concerning the financial aspects of insurance contract conclusion since most indicators used in the western reality are not so different from those used in Poland [8]. This issue has recently raised a lot of controversy and it is not so easy to solve. Very often, the only agent evaluation criterion is their volume of output. If it is not satisfactory, the company terminates an agent's contract and they lose the whole portfolio of clients. They are deprived of their income source while the company decreases the acquisition costs. Insurance companies who avail of such a strategy are particularly common in Poland, and they even receive awards for effectiveness [9].

However, this is a multi-dimensional problem, which applies to many management levels in organisations selling life insurance. The rotation of insurance agents may even reach $94 \%$ in four years and the situation of the middle management does not seem to be better. Instead of actively supporting the sales department, they are snowed under with administrative duties, oftentimes not very effective [10].

\section{The activities of agents-entrepreneurs in the} context of insurance company strategies effectiveness - conclusions

In the "Old" European Countries, clients expect from an insurance agent to be professional, trustworthy and most of all, honest. It is in the agent's and the company's interest to provide a client with the best advice: choose together with the client the most advantageous insurance option, explain things clearly and holistically, and connect many factors together. Misselling may result in both financial and legal consequences, the most harmful of which seems to be "professional casualty" as misselling results in spreading information about the agent's dishonest approach, which in turn, reduces the number of people interested in any cooperation with such an agent [11]. The insurance market in Poland became more mature after the reform, and it is ready for a new phase, where insurance agents are fully professional, perfectly trained and deal exclusively with sales. In 2013, among the agents of one of the largest insurance companies operating in Poland, 
there were $57 \%$ of women and $55 \%$ of men who had university degree (Table 4).

Table 4

Agents' education

\begin{tabular}{|c|c|c|}
\hline Type of education & $\mathrm{M}[\%]$ & $\mathrm{F}[\%]$ \\
\hline Non-technical secondary education & 17 & 21 \\
\hline Technical secondary education & 26 & 19 \\
\hline Non-technical university education & 19 & 47 \\
\hline Technical university education & 33 & 8 \\
\hline
\end{tabular}

Source: the author's own research

Presently, recruitment processes aim at employing only people with higher education.

In the UK, if agents have more than $15 \%$ insurance policies cancelled, they are forbidden from selling until they improve their results. They are also not allowed to start cooperating with another company. Moreover, an agent should be highly qualified in finance. This is supervised by the Financial Services Authority FSA, an organization, which is seemingly similar to Polish KNF. However, it has completely different tasks, for example, it keeps the register of agents, controls quality and carries out exams authorising one to become an insurance agent (insurance companies have maintained the right to train their agents on their own). Additionally, insurance companies pay a charge for every agent to this authority.

Another factor to consider for insurance companies are distribution channels. An agent is the most effective, but also the most costly to obtain clients and maintain one's business. Some boards of insurance companies conducting their business in Poland have decided to change agency contracts, which caused a host of agents to resign from cooperation. In extreme cases, reduction of the sales department has even reached $70 \%$. Here, a question should be asked if this is a short-term policy aiming at showing the highest profit to the shareholders and pay out bonuses to boards, or if it is an element of a long-term strategy leading to effectiveness and business quality improvement. Considering the fact that a number of agents made redundant have actually been quite successful in sales since they started working for the competitor, and that rotation among insurance companies board members is rather high, this situation cannot be interpreted only in one way, especially that there are countries which gave up agent mediation almost completely. In Italy, for example, "cross selling" in banks is more popular and a significant number of contracts is concluded on the Internet. Life insurance, due to its complexity, is rarely offered on the Internet (there are only offers of the simplest products). However, one cannot exclude this possibility once e-signature is introduced. On the basis of the observed life insurance market changes, it can be concluded that in the next years, we are not going to face any breakthrough changes in this area if the Polish legislation is not correlated with the European market norms. At present, the law successfully restricts the development of the insurance agent profession in the following ways:

- lack of legislation concerning e-signature is an effective obstacle to sell life insurance on the Internet, - since 15.01.2005 [12], there has been an obligation to conclude a civil liability insurance contract for a guarantee amount of EUR1,000,000 by those agents who work for a few insurance companies or by insurance brokers, which will force many people to resign from their jobs as agents and brokers due to very high costs of this insurance.

\section{Conclusions}

The legislator does not make it obligatory for agents working only for one company to conclude a civil liability contract. Therefore, a question arises: was this law supposed to make it difficult for agents to extend their business activity, which is against the normative conditions of the EU, as in the Polish market there is not a single life insurance company which would have a portfolio of products large enough to enable an agent to become a professional customer assistant, or is this just a means to reduce the budget deficit? In accordance with the rule of freedom to provide insurance services, an insurance agent can provide services in any Member State. Therefore, there is a high probability that a considerable part of the insurance market will be lost to foreign entrepreneurs who pay taxes in their home countries. The insurance business is now dominated by numerous disputes concerning whether some amendments to the latest Insurance Activity Act instead of helping Polish entrepreneurs, who will soon be confronted with a much stronger competition, actually makes the profession of a Polish insurance agent in danger of extinction.

\section{References}

1. Sangowski, T. Vademecum ubezpieczeń gospodarczych [Business insurance vademecum] [Text] / T. Sangowski. - Poznań 2000. Saga Printing, 2000. - P. 45-46.

2. Act of 22 May 2003. Dz. U. [Electronic resource] / Journal of Laws, 2003. - P. 1-29. - Available at: https://www.knf.gov.pl/en/Images/act_on_insurance_mediation _tcm81-4295.pdf

1154

3. Dz. U. [Text] / Journal of Laws. - No. 124. - Item

4. Dz. U. Business Activity Act [Text] / Journal of Laws. - No. 101. - Item 1178.

5. Doan, O. Ubezpieczenia życiowe [Life insurance] [Text] / O. Doan. - Poltex. Warsaw, 1995. -89 p.

6. PUNU. Selected acts of law concerning Insurance Activity [Text] / Książka i Wiedza. Warsaw, 1999. - 116 p.

7. Pocztowski, A. Zarządzanie zasobami ludzkimi [Human Resources Management] [Text] / A. Pocztowski. PWE. Warsaw, 2003. - 43 p.

8. Balewski, B. Human Performance:Competencies, effectiveness and talent management [Text] / B. Balewski, A. Janowski. - Torun. UMK Publishing, 2011.

9. Janowski, A. Does the personality matter - talent management in life insurance organizations - future perspectives [Text] / A. Janowski. - Acta oeconomica cassoviensia. Ekonomická univerzita v Bratislave, 2013. P. 55-76.

10. Drucker, P. The essential Drucker [Text] / P. Drucker. - MT Biznes, 2001. - 401 p.

11. Balewski, B. Talent Management in Life Insurance Industry, Rediscovering L. von Mises Theory [Text] / B. Balewski, A. Janowski // Journal of US-China Public Administration. - 2014. - Vol. 5. - P. 440-453 
12. Ministry of Finance Regulation of 04.12.2004. Dz. U. [Text] / Journal of Laws. - No. 211. - Item 2066.

\section{References}

1. Sangowski, T. (2000). Vademecum ubezpieczeń gospodarczych [Business insurance vademecum]. Poznań 2000. Saga Printing, 45-46.

2. Act of 22 May 2003. Dz. U. (2003). Journal of Laws, 1-29. Available at: https://www.knf.gov.pl/en/Images/ act_on_insurance_mediation_tcm81-4295.pdf

3. Dz. U. Journal of Laws. No. 124. Item 1154

4. Dz. U. Business Activity Act. Journal of Laws. No. 101. Item 1178.

5. Doan, O. (1995). Ubezpieczenia życiowe [Life insurance]. Poltex. Warsaw, 89.

6. PUNU. Selected acts of law concerning Insurance Activity (1999). Książka i Wiedza. Warsaw, 116.
7. Pocztowski, A. (2003). Zarządzanie zasobami ludzkimi [Human Resources Management]. PWE. Warsaw, 43.

8. Balewski, B., Janowski, A. (2011). Human Performance:Competencies, effectiveness and talent management. Torun. UMK Publishing.

9. Janowski, A. (2013). Does the personality matter talent management in life insurance organizations - future perspectives. Acta oeconomica cassoviensia. Ekonomická univerzita v Bratislave, 55-76.

10. Drucker, P. (2001). The essential Drucker. MT Biznes, 401.

11. Balewski, B., Janowski, A. (2014). Talent Management in Life Insurance Industry, Rediscovering L. von Mises Theory. Journal of US-China Public Administration, 5, $440-453$

12. Ministry of Finance Regulation of 04.12.2004. Dz. U. Journal of Laws. No. 211. Item 2066.

Дата надходження рукопису 26.01.2015

Andrzej Janowski, PhD, The Headmaster of Banking and Insurance Faculty, Higher School of Personnel Management in Konin, Powstańców Wielkopolskich st. 16, Konin, Poland, Zip Code 62-500

E-mail: andrzej.j@poczta.fm

УДК: 332.1:330.322

DOI: $10.15587 / 2313-8416.2015 .36767$

\section{ПІДХОДИ ДО РЕЙТИНГУВАННЯ СОЦАЛЬНО-ЕКОНОМІЧНИХ ПРОБЛЕМ ТЕРИТОРІАЛЬНИХ УТВОРЕНЬ}

\section{(C) Н. Ю. Голуб}

У статті досліджено питання визначення пріоритетності соціально-економічних проблем територіальних утворень. Запропоновано науково-методичний підхід до рейтингування соиіальноекономічних проблем територіального утворення, які можуть бути вирішені з використанням інструментів сочіального інвестування. Обтрунтовано доиільність застосування даного підходу для територіальних утворень різних рівнів підпорядкування

Ключові слова: рейтингування, соціально-економічні проблеми, територіальні утворення, соціальне інвестування, місчеве самоврядування

A definition of priority ranking of social and economic problems of territorial entities is investigated in the article. Scientific and methodological approach to rating of social and economic problems of territorial entities which can be solved by using tools of social investment is proposed. Viability of using this approach for territorial entities of different levels of jurisdiction is proved

Keywords: rating, social and economic problems, territorial entities, social investment, local self-government

\section{1. Ветуп}

В сучасних умовах соціально-економічний розвиток України безпосередньо залежить від рівня інтенсивності розвитку іiі регіонів, який в свою чергу визначається темпами економічного зростання міст та соціальної активністю суб'єктів господарювання, що знаходяться на їх території. Однак наявність широкого кола економічних, соціальних та екологічних проблем стримують розвиток територіальних утворень. Їх поступове вирішення можливе тільки за умови тісної співпраці всіх груп зацікавлених сторін - стейкхолдерів (місцевого співтовариства, громадських організацій, соціально відповідального бізнесу, наукових установ, органів місцевої, регіональної та державної влади) та застосування сучасних інструментів, зокрема соціального інвестування.

\section{2. Постановка проблеми}

Значення соціального інвестування полягає в можливості цільового залучення ресурсів для вирішення пріоритетних соціально-економічних проблем місцевих громад. При цьому резуль-тативність застосування інструментів соціального інвестування, яке полягає в поліпшенні якості життя людей, може бути в повній мірі досягнута за умови попереднього детального дослідження соціально-економічних проблем, які властиві конкретній адміністративнотериторіальній одиниці (регіону, району, місту або селищу), та визначення найбільш пріоритетних з них. Зазначене обумовлює актуаль-ність питань розробки 